\title{
Productivity and the Post-1990 U.S. Economy
}

\author{
Ellen R. McGrattan and Edward C. Prescott
}

\begin{abstract}
In this paper, the authors show that ignoring corporate intangible investments gives a distorted picture of the post-1990 U.S. economy. In particular, ignoring intangible investments in the late 1990s leads one to conclude that productivity growth was modest, corporate profits were low, and corporate investment was at moderate levels. In fact, the late 1990s was a boom period for productivity growth, corporate profits, and corporate investment.
\end{abstract}

Federal Reserve Bank of St. Louis Review, July/August 2005, 87(4), pp. 537-49.

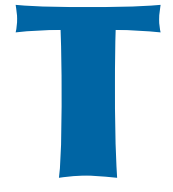

he standard measure of productivity is gross domestic product (GDP) per hour worked. The thesis of this paper is that this measure of productivity is not a good measure of actual output produced per hour worked, which we call economic productivity. The reason is that output is understated by GDP because many investments are not accounted for in the U.S. Department of Commerce's Bureau of Economic Analysis (BEA) measure of product. If the importance of these unaccounted investments relative to GDP remained constant over time, growth in GDP per hour would be equal to growth in economic productivity. But in the post-1990 U.S. economy, the relative importance of these investments varied a lot. We find that excluding them in the measure of U.S. output leads to a large underestimate of productivity growth in the late 1990s.

In this paper, these unaccounted investments will be called intangible investments. ${ }^{1}$ They are

1 We use this term because the bulk of the investments are not tangible. expenditures that increase future profits but, by national accounting rules, are treated as an operating expense rather than as a capital expenditure. Examples include advertising, research and development, and, most important of all, investments in building organizations. Most intangible investments are not directly observable, but they can be inferred using standard growth theory and data from the U.S. national income and product accounts (NIPA). We do this and show that movements in accounting and economic measures of productivity are very different during the 1990s. In particular, we find that productivity growth prior to 1997 was even weaker than suggested by GDP per hour worked, that there was a productivity boom in the late 1990s, and that productivity growth returned to its low level subsequent to the boom.

Our accounting has other implications, in particular, for corporate profits and corporate investment. In the late 1990s output boom, the corporate profit share reported by the BEA was low. (See U.S. Department of Commerce, 19292004.) A low profit share is not typical in booms.

Ellen R. McGrattan is a monetary advisor at the Federal Reserve Bank of Minneapolis and an adjunct professor of economics at the University of Minnesota. Edward C. Prescott is the W.P. Carey Professor of Economics at Arizona State University and a senior monetary advisor at the Federal Reserve Bank of Minneapolis. Data are also available at the website of the Federal Reserve Bank of Minneapolis:

www.minneapolisfed.org. The authors thank Ricardo Caballero for helpful comments on an earlier draft. They also thank the National Science Foundation for financial support. The views expressed herein are those of the authors and not necessarily those of the Federal Reserve Bank of Minneapolis or the Federal Reserve System.

(C) 2005, The Federal Reserve Bank of St. Louis. Articles may be reprinted, reproduced, published, distributed, displayed, and transmitted in their entirety if copyright notice, author name(s), and full citation are included. Abstracts, synopses, and other derivative works may be made only with prior written permission of the Federal Reserve Bank of St. Louis. 
The reason the corporate profit share fell in the boom is simple accounting: Accounting profits understated economic profits because corporations were making large intangible investments in the late 1990s that they expensed. Adding intangible investments to accounting profits and to accounting investment implies a very different picture of the U.S. economy than is evident in the BEA data because adjusted corporate profit and corporate investment shares were both high.

\section{THE MODEL ECONOMY}

In this section, we present a version of the model economy that we used to analyze secular movements in corporate equity values. (See McGrattan and Prescott, 2004.) Here, we use the model to compare accounting and economic measures of key aggregate statistics.

The economy is populated by a large number of identical, infinitely lived households. They make decisions about consumption, labor supply, and saving. These decisions are event contingent, where the events are generated by a finite-state Markov chain with stationary transition probabilities. The period $t$ state is $s_{t} \in S$.

Preferences of the stand-in household are ordered by

$$
E \sum_{t=0}^{\infty} \beta^{t} U\left(C_{t} / N_{t}, L_{t} / N_{t}\right),
$$

where $C_{t}$ is total consumption, $L_{t}$ is total labor supply, and $N_{t}$ is the working-age population.

There are two stand-in firms, one for the corporate sector and one for the noncorporate sector. The constant-returns technology for the corporate sector, sector 1, is given by

$$
\begin{gathered}
Y_{1, t}=f^{c}\left(K_{1 m, t}, K_{1 u, t}, L_{1, t}, s_{t}\right) \\
K_{1 m, t+1}=\left(1-\delta_{1 m}\right) K_{1 m, t}+X_{1 m, t} \\
K_{1 u, t+1}=\left(1-\delta_{1 u}\right) K_{1 u, t}+X_{1 u, t} \\
\hat{K}_{1 m, t+1}=\left[\left(1-\hat{\delta}_{1 m}\right) \hat{K}_{1 m, t}+\left(1-\hat{\delta}_{1 x}\right) X_{1 m, t}\right] /\left(1+\pi_{t, t+1}\right),
\end{gathered}
$$

where $Y_{1, t}$ is the output of the sector, $K_{1 m, t}$ is the beginning-of-period stock of measured capital, $K_{1 u, t}$ is the beginning-of-period stock of unmea- sured capital, $\hat{K}_{1 m, t}$ is the beginning-of-period book value of the stock of measured capital, $L_{1, t}$ is the labor input, $X_{1 m, t}$ is new investment in measured capital, $X_{1 u, t}$ is new investment in unmeasured capital, and $\pi_{t, t+1}$ is the inflation rate between $t$ and $t+1$. Later, we use the fact that $f^{c}$ has a unit elasticity between capital and labor, with the capital share equal to $\theta$.

Stocks $K_{1 m, t}$ and $\hat{K}_{1 m, t}$ can be different if tax rules allow for differences between depreciation for taxes and actual economic depreciation. They can also be different if there is inflation. The stocks of measured and unmeasured capital depreciate at rates $\delta_{1 m}$ and $\delta_{1 u}$, respectively. For tax purposes, capital consumption allowances are equal to $\hat{\delta}_{1 m} \hat{K}_{1 m, t}+\hat{\delta}_{1 X} X_{1 m, t}$ and can exceed $\delta_{1 \mathrm{~m}} K_{1 \mathrm{~m}, t}$ because of accelerated depreciation allowances or allowances by the Internal Revenue Service for expensing tangible investments.

The constant-returns technology for the noncorporate sector, sector 2 , is

$$
\begin{gathered}
Y_{2, t}=f^{n c}\left(K_{2 m, t}, L_{2, t}, s_{t}\right) \\
K_{2 m, t+1}=\left(1-\delta_{2 m}\right) K_{2 m, t}+X_{2 m, t} \\
\hat{K}_{2 m, t+1}=\left[\left(1-\hat{\delta}_{1 m}\right) \hat{K}_{2 m, t}+\left(1-\hat{\delta}_{1 X}\right) X_{2 m, t}\right] /\left(1+\pi_{t, t+1}\right),
\end{gathered}
$$

where $Y_{2, t}$ is the output of the sector, $K_{2 m, t}$ is the beginning-of-period stock of measured capital, $\hat{K}_{2 m, t}$ is the beginning-of-period book value of the stock of measured capital, $L_{2, t}$ is the labor input, and $X_{2 m, t}$ is new investment in measured capital. Later, we use the fact that $f^{n c}$ has a unit elasticity between capital and labor, with the capital share equal to $\alpha$.

The rate of economic depreciation of noncorporate capital is $\delta_{2 m}$. For tax purposes, total depreciation is $\hat{\delta}_{2 m} K_{2 m, t}+\hat{\delta}_{2 x} X_{2 m, t}$. We assume that intangible capital investment in the noncorporate sector is negligible and therefore do not include it. $^{2}$

Policy in this economy is a set of tax rates and transfer functions that depend on the state $s_{t}$. Both the households and the firms pay taxes.

\footnotetext{
2 Most of the investment in the noncorporate sector is in the household and government sectors, with little or no expenditures on items such as research and development, advertising, and investments in organizational capital.
} 
We consider recursive competitive equilibria with equilibrium elements that are stationary functions of the economy's state vector. Because of our assumption that $s_{t}$ is a Markov process with time-invariant transition probabilities, the aggregate state in period $t$ is $\left(K_{1 m, t}, K_{1 u, t}, \hat{K}_{1 m, t}, K_{2 m, t}\right.$, $\left.\hat{K}_{2 m, t}, s_{t}\right)$. For convenience, let $K_{t}=\left(K_{1 m, t}, K_{1 u, t}\right.$, $\hat{K}_{1 m, t}, K_{2 m, t}, \hat{K}_{2 m, t}$ ). For a stationary recursive equilibrium, the state in period $t$ is a function of the period $t$ event history $s^{t}=\left(s_{0}, \ldots s_{t}\right)$, a fact that we use later.

The problem of the household is to maximize (1) subject to the period $t$ budget constraints:

(2)

$$
\begin{aligned}
& \left(1+\tau_{c, t}\right) C_{t}+A_{t+1} \\
& =\left(1-\tau_{d, t}\right) D_{1, t}+D_{2, t}+\left(1-\tau_{n, t}\right) W_{t} L_{t}+\left(1+i_{t}\right) A_{t}+T_{t},
\end{aligned}
$$

where $A_{t}$ is asset holdings at the beginning of period $t$. The household, during period $t$, receives income from corporate and noncorporate distributions, $D_{1, t}$ and $D_{2, t}$, respectively, wages at aftertax rate $\left(1-\tau_{n, t}\right) W_{t}$, assets at after-tax rate $i_{t}$, and net transfers from the government, $T_{t}$. Distributions $D_{1, t}$ and $D_{2, t}$ are both net of taxes paid by corporate and noncorporate firms.

Corporate firms maximize the present value of after-tax distributions to the household, namely,

$$
\sum_{t} \sum_{s^{t}}\left(1-\tau_{d, t}\left(s^{t}\right)\right) p_{t}\left(s^{t}\right) D_{1, t}\left(s^{t}\right)
$$

Corporate distributions are

$$
\begin{aligned}
D_{1, t} & =p_{1, t} Y_{1, t}-W_{t} L_{1, t}-X_{1 m, t}-q_{t} X_{1 u, t} \\
& -\tau_{1, t}\left[p_{1, t} Y_{1, t}-W_{t} L_{1, t}-\hat{\delta}_{1 m} \hat{K}_{1 m, t}-\hat{\delta}_{1 X} X_{1 m, t}\right. \\
& \left.-\tau_{1 k, t} K_{1 m, t}-q_{t} X_{1 u, t}\right] \\
& -\tau_{1 k, t} K_{1 m, t}+\tau_{x, t} X_{1 m, t .}
\end{aligned}
$$

Noncorporate firms maximize the present value of distributions, namely,

$$
\sum_{t} \sum_{s^{t}} p_{t}\left(s^{t}\right) D_{2, t}\left(s^{t}\right)
$$

Thus, noncorporate distributions are

$$
\begin{aligned}
D_{2, t} & =p_{2, t} Y_{2, t}-W_{t} L_{2, t}-X_{2 m, t} \\
& -\tau_{2, t}\left[p_{2, t} Y_{2, t}-W_{t} L_{2, t}-\hat{\delta}_{2 m} \hat{K}_{2 m, t}\right. \\
& \left.-\hat{\delta}_{2 x} X_{2 m, t}-\tau_{2 k, t} K_{2 m, t}\right] \\
& -\tau_{2 k, t} K_{2 m, t}+\tau_{x, t} X_{2 m, t .}
\end{aligned}
$$

Note that income taxes are paid once on noncorporate income (net of proprietors' implicit labor income).

There is a final goods producer that combines corporate and noncorporate goods to solve

$$
\max _{y_{1}, y_{2}} F\left(Y_{1}, Y_{2}\right)-p_{1} Y_{1}-p_{2} Y_{2} .
$$

The composite output $Y=F\left(Y_{1}, Y_{2}\right)$ good is used for consumptions and investments:

$$
Y_{t}=C_{t}+X_{1 m, t}+q_{t} X_{1 u, t}+X_{2 m, t}+G_{t},
$$

where $G_{t}$ is government consumption. The function $F$ displays constant returns to scale. An implication is that equilibrium distributions are zero, and therefore we do not consider these distributions.

There is growth in the economy due to population growth and productivity. We detrend income and product variables by dividing first by population and second by $(1+\gamma)^{t}$, the trend in productivity. To construct hours per capita, we divide total labor input by population. We adopt the notation of lowercase letters for variables that are stationary. For example, $c_{t}=C_{t} /\left[N_{t}(1+\gamma)^{t}\right]$ is detrended consumption and $\ell_{t}=L_{t} / N_{t}$ is detrended labor supply.

It is also convenient to introduce notation for the marginal products of capital. Let $r_{1 m, t}, r_{1 u, t}$, and $r_{2 m, t}$ be the marginal products of measured corporate capital, unmeasured corporate capital, and measured noncorporate capital, respectively.

We now are ready to lay out the national accounts for our model economy.

\section{NATIONAL ACCOUNTS TO MODEL ECONOMY ACCOUNTS}

In this section, we specify the mapping from U.S. national accounts to the model economy accounts. Our model accounts are summarized in Table A1 in the appendix, with formula specifying entries as a function of model variables. Table A2 reports the main categories of the U.S. national accounts, with average values relative to GDP in the 1990s. Table A3 specifies the model account numbers as a function of the statistics in 
the U.S. national accounts and the values of these statistics. $^{3}$

\section{Adjustments}

There are four important differences between the accounts our model economy dictates and the U.S. national accounts. First, our model output does not include consumption taxes as part of consumption and as part of value added, but NIPA GDP does. A consequence of this is that, unlike NIPA, our accounts are consistent in using producer prices for inputs and outputs. Second, we treat some financial services included in NIPA as intermediate rather than as final. Third, our model treats expenditures on all fixed assets as investment. Thus, consumer durables are treated as an investment in the model accounts rather than as consumption expenditures. We introduce a consumer durable services sector in much the same way as an owner-occupied housing sector is introduced into NIPA. Households rent the consumer durables to themselves. A related adjustment is made for government capital. Finally, and most importantly for the purposes of this paper, our model output includes corporate intangible investment. Intangible investments are expensed and therefore not included in the national accounts.

Adjustments for Consumption Tax. Our consumption taxes are all non-property taxes on production and imports less subsidies plus business current transfer payments. The reason that we include business transfers in consumption taxes is that they are mostly liability payments, which de facto are a tax. NIPA reports total consumption taxes, which we must assign to the corporate and noncorporate sectors. The sums of consumption and property taxes are reported by sector. We assign aggregate consumption taxes to sectors in proportion to their sums of consumption and property taxes. We subtract the consumption tax from the value added of each sector.

On the product side we assume that all components of NIPA personal consumption expenditures, which include consumer durable expenditures,

3 Numbered lines in Table A3 correspond to numbered lines in Table A1. are taxed at an equal rate. In fact a small part of what we call consumption taxes falls on other components of product, but we do not have good estimates of how much. Thus, we make the simplifying assumption that all consumption taxes fall on personal consumption expenditures. Fortunately, the assignment does not affect the results of this study.

The results of our adjustments for consumption taxes are summarized in Table A3 (lines 4, 8, 10, and 14).

Adjustments for Intermediate Services. Corporate value added includes some services that are not included in our notion of final goods or services. ${ }^{4}$ In particular, NIPA imputes to net interest and to consumption an amount equal to the expenses of handling life insurance and pensions, which are intermediate goods in the production of a final good, namely, a diversified financial portfolio. On the income side, we subtract these expenses (which are about 1 percent of GDP) from corporate net interest (Table A2, line 6). On the product side, we subtract these expenses from personal consumption expenditures (Table A2, line 16).

In our mapping from national accounts to model accounts in Table A3, these calculations are listed as "imputed personal business expense." They appear under capital income (line 4) and private consumption (line 10).

Adjustments for Capital Services. We make adjustments in our model accounts for consumer durables and government capital so as to treat them like all other fixed assets accounted for in NIPA.

The implicit rental price of consumer durables that we use is consumer durable depreciation divided by the value of the stock of durables plus the after-tax return on capital. Using estimates from McGrattan and Prescott (2004), we assume that the return is 4.1 percent per year. ${ }^{5}$ The imputation to consumption is this rental price times the stock of consumer durables. There are two imputa-

\footnotetext{
4 There have been major changes recently in the accounting of financial services. Most intermediate services are now excluded from GDP.

5 If $i$ is not close to this value, then returns to capital in the model are not consistent with observed capital stocks and tax rates.
} 
tions to value added. First, we add depreciation of consumer durables to noncorporate depreciation. Second, we add the return on capital times the stock of consumer durables to noncorporate profits.

In Table A3, these calculations are summarized in imputed capital services under noncorporate capital income (line 8) and private consumption (line 10).

In NIPA, the services of government capital are equal to its depreciation. Thus, net income is zero. We define net income of government capital as our average after-tax return on capital (4.1 percent) times the value of this capital stock. We add this income to profits of the noncorporate sector on the value added side of the accounts and to public consumption on the product side.

In Table A3, these calculations are summarized in imputed capital services under noncorporate capital income (line 8) and public consumption (line 11).

Adjustments for Intangible Investments. The last adjustment we make to corporate income is to add back investments that had been expensed. We do not have direct measures of these expenses but can infer them from our theory and NIPA data. In this section, we use the theory to estimate the average level of intangible investment and the equilibrium path since 1990.

The Average Level of Intangible Investment in the 1990s. As in McGrattan and Prescott (2004), we can take an indirect approach, using observations on corporate profits and returns to tangible assets to estimate a return to intangible assets. NIPA profit before corporate income tax is

NIPA profit $=$

$$
\begin{aligned}
& r_{1 m} k_{1 m}+r_{1 u} k_{1 u}-\delta_{1 m} k_{1 m}-\tau_{1 k} k_{1 m}-q x_{1 u} \\
& =\left(r_{1 m}-\delta_{1 m}-\tau_{1 k}\right) k_{1 m}+q\left(r_{1 u} / q k_{1 u}-x_{1 u}\right) .
\end{aligned}
$$

If economic and accounting depreciation are equal and returns are equated for all assets, then the first-order conditions of the model in the section "The Model Economy” imply that the following hold ${ }^{6}$ :

\footnotetext{
6 We also did calculations allowing for differences in the depreciation rates. Holding the corporate tax rate fixed, we find a higher average level of intangible investment if accounting depreciation exceeds economic depreciation. Thus, to be conservative in our conclusions about the importance of intangible investment, we assume economic and accounting depreciation are equal.
}

$$
\begin{gathered}
i=r_{1 u} / q-\delta_{1 u} \\
i=\frac{\left(1-\tau_{1}\right)\left(r_{1 m}-\tau_{1 k}\right)+\tau_{1} \delta_{1 m}}{1-\tau_{x}}-\delta_{1 m} \\
x_{1 u}=\left(\gamma+\eta+\delta_{1 u}\right) k_{1 u} \\
x_{1 m}=\left(\gamma+\eta+\delta_{1 m}\right) k_{1 m}
\end{gathered}
$$

on a balanced growth path, where $i$ is the real interest rate and $\eta$ is the population growth rate.

Equations (3) through (7) can be solved for the average level of intangible investment and capital. This is done as follows. We use BEA data to get estimates of the corporate income tax rate, $\tau_{1}$, the corporate property tax rate, $\tau_{1 k}$, the subsidy to investment, $\tau_{x}$, the tangible depreciation rate, $\delta_{1 m}$, and corporate tangible investment, $x_{1 m}$. We can use either the noncorporate returns or estimates of preference parameters to get the real interest rate, $i$. Population growth, $\eta$ is around 1 percent per year. Trend technology growth, $\gamma$, is around 2 percent per year.

The system of equations (3) through (7) is five equations in the five unknowns, $r_{1 u} / q-\delta_{1 u}, r_{1 m}$, $q k_{1 u}, k_{1 m}$, and $q x_{1 u}$. Using data from the 1990s, our estimate of the average value of intangible capital, $q k_{1 u}$, is 0.65 times GDP. ${ }^{7}$ This estimate is independent of our choice of $\delta_{1 u}$. Our estimate of net investment, $q x_{1 u}-\delta_{1 u} k_{1 u}$, is also independent of our choice of $\delta_{1 u}$. Net intangible investment averaged 2 percent of GDP. ${ }^{8}$

The Equilibrium Path of Intangible Investment Since 1990. We can infer the path for intangible investment using intratemporal first-order conditions of the model. We use two approaches that lead to similar quantitative implications for productivity in the 1990s. The two approaches rely on different assumptions about cost shares over the business cycle.

Our first approach assumes that the capital income share does not vary over the cycle. Let $\theta$ be the capital share in the corporate sector, which

\footnotetext{
7 The inputs to this calculation are $\tau_{1}=0.37, \tau_{1 k}=0.02, \tau_{x}=0$, $\delta_{1 m}=0.06, x_{1 m}=0.099, i=0.041, \gamma=0.02$, and $\eta=0.01$.

8 For convenience we will set $\delta_{1 u}=0$ when we derive time series for $q_{t} x_{1 u, t}$. We are, in effect, working with net intangible investment.
} 


\section{Figure 1}

\section{Intangible Investment (Corporate Income Shares Fixed)}

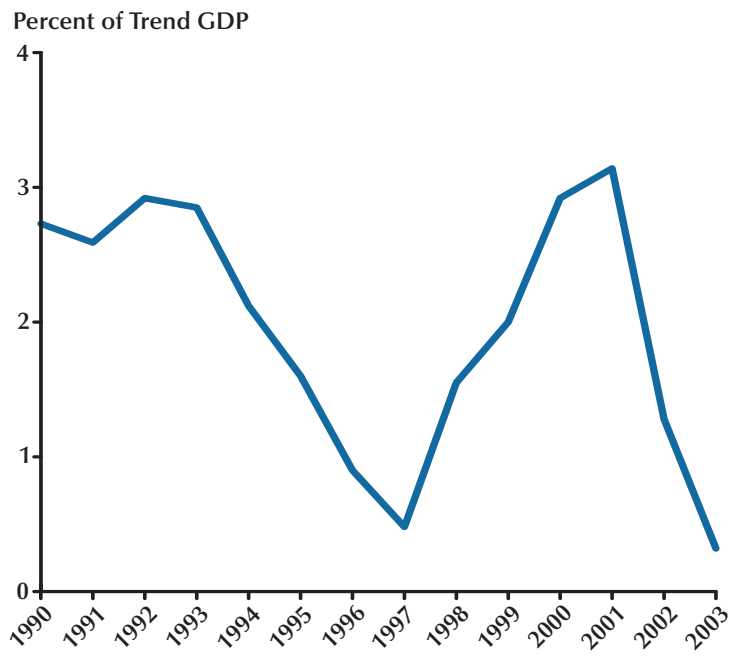

we take to be the average corporate capital income share, $\left(r_{1 m} k_{1 m}+r_{1 u} k_{1 u}\right) /\left(p_{1} y_{1}\right)$, or, equivalently, 1 less the average corporate labor income share, $1-w \ell_{1} /\left(p_{1} y_{1}\right)$. Using averages in the 1990s, we estimate an average corporate capital share of $\theta=0.33$. If intangible investments are chosen so that

$$
\begin{aligned}
\frac{w_{t} \ell_{1, t}}{p_{1, t} y_{1, t}} & =1-\theta_{t} \\
& =1-\theta,
\end{aligned}
$$

then $q_{t} x_{1 u, t}$ satisfies

$$
\begin{aligned}
w_{t} \ell_{1, t} & =(1-\theta) p_{1, t} y_{1, t} \\
& =(1-\theta)\left[\mathrm{va}_{1, t}^{\text {accounting }}+q_{t} x_{1 u, t}\right],
\end{aligned}
$$

where we have an estimate of $\theta$ and time series for corporate compensation $\left(w_{t} \ell_{1, t}\right)$ and accounting corporate value added ( $\mathrm{va}_{1, t}^{\text {accounting }}$ ). The unknown in equation (8) is the product $q_{t} x_{1 u, t}$.

In Figure 1, we display the implied time series for intangible investment after 1990. What is striking about this figure is the sixfold increase in the level of intangible investments between 1997 and 2000. This represents a very large change in investment. This change in investment has con-

\section{Figure 2}

\section{Productivity Relative to a 2 Percent Trend (Corporate Income Shares Fixed)}

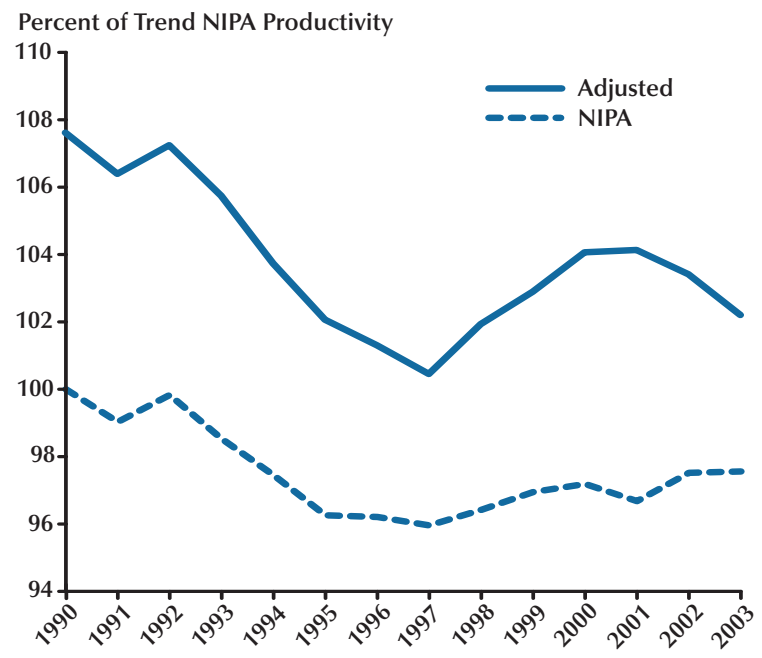

sequences for output, profits, and total investment.

Output is the sum of corporate and noncorporate income, namely, $y_{t}$, after the relevant adjustments to the national accounts are made. Economic corporate profits are capital income, which is corporate income less labor income and depreciation. If we assume an intangible depreciation rate of zero, then economic corporate profits are given by ${ }^{9}$

$$
p_{1, t} y_{1, t}-w_{t} \ell_{1, t}-\delta_{1 m} k_{1 m, t} .
$$

Economic corporate investment is the sum of tangible plus intangible investments. Economic profit shares and investment shares are defined relative to output, $y_{t}$, rather than GDP.

In Figure 2, we compare the standard measure of productivity, real GDP per hour worked, with our economic measure $y_{t} / \ell_{t}$. The hours measure we use is described in Prescott and Ueberfeldt (2003) and based on the Current Population Survey. We normalize hours to be 1 in 1990 so that we can directly compare the magnitudes of

9 In McGrattan and Prescott (2004), we do a sensitivity analysis that includes varying $\delta_{1 u}$. 


\section{Figure 3}

\section{Corporate Profit Shares of Income (Corporate Income Shares Fixed)}

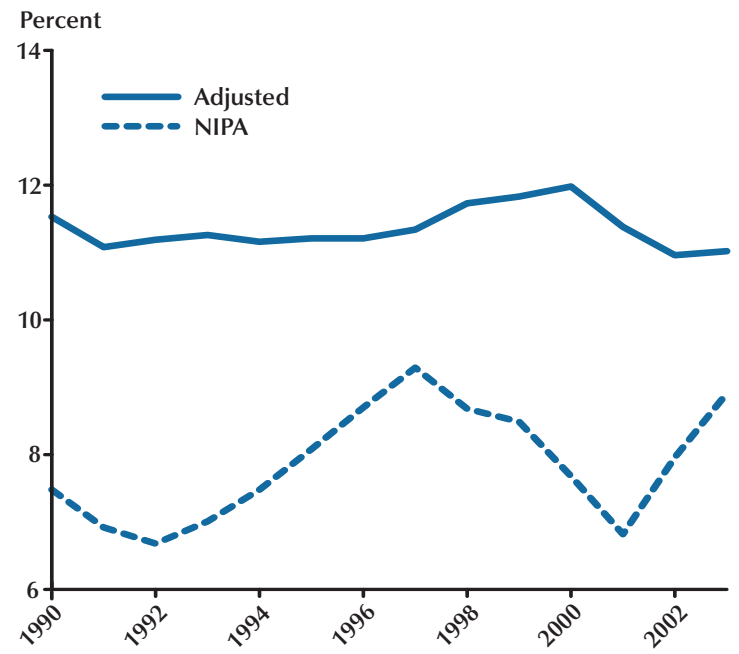

GDP and $y$. We also divide both measures by $1.02^{t}$, the historical trend.

The figure shows that economic productivity fell faster than accounting productivity in the early 1990s but grew much faster at the end of the 1990s. Notice that economic productivity is higher than accounting productivity in 1990 because output, $y$, is 8 percent higher than GDP. A comparison with Figure 1 illustrates how important the movements in intangible investment are for output.

In Figure 3, we plot the accounting measure of corporate profits relative to GDP and our economic corporate profits relative to output. Our measure is significantly higher because we do not subtract intangible investment or property tax. Our measure also includes the small part of corporate net interest that is not intermediate services. Our profit share is about 12 percent, whereas NIPA's profit share is 7.5 percent.

Of particular significance is the fact that the patterns are very different. In the late 1990s, economic profits are high, while NIPA profits are low.

In Figure 4, we plot the accounting measure of the corporate investment share, namely, corporate tangible investment relative to GDP and

\section{Figure 4}

\section{Corporate Investment Shares of Income (Corporate Income Shares Fixed)}

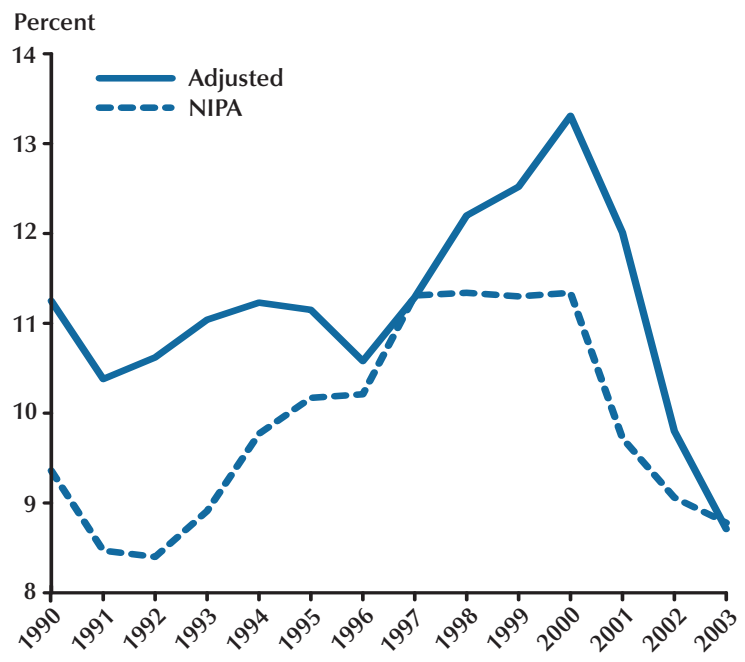

our economic measure, which is total corporate investment-tangible and intangible-divided by output, $y$. Notice that the standard accounting measure shows only a modest investment boom in the late 1990s, whereas our measure shows a bigger investment boom.

Our second approach to measuring the path of intangible investment assumes that the ratio of labor income shares across sectors is constant. Let $1-\theta_{t}$ be the corporate labor income share in period $t$ and let $1-\alpha_{t}$ be the noncorporate labor income share in period $t$. Thus, our second approach assumes that

$$
\frac{1-\theta_{t}}{1-\alpha_{t}}=\frac{1-\theta}{1-\alpha}
$$

where $\theta$ and $\alpha$ are found by taking averages over our sample period. For the corporate sector, the average is $\theta=0.33$. For the noncorporate sector, the average is $\alpha=0.496 .{ }^{10}$

Assuming that corporate income shares stay constant puts a lower bound on the increase of intangible investment during the late 1990s, as

\footnotetext{
${ }^{10}$ The capital cost share for the noncorporate sector is high because a significant fraction of this sector's capital is housing and consumer durables, which have a capital cost share near 1.
} 


\section{Figure 5}

\section{Intangible Investment (Corporate Income Shares Varying)}

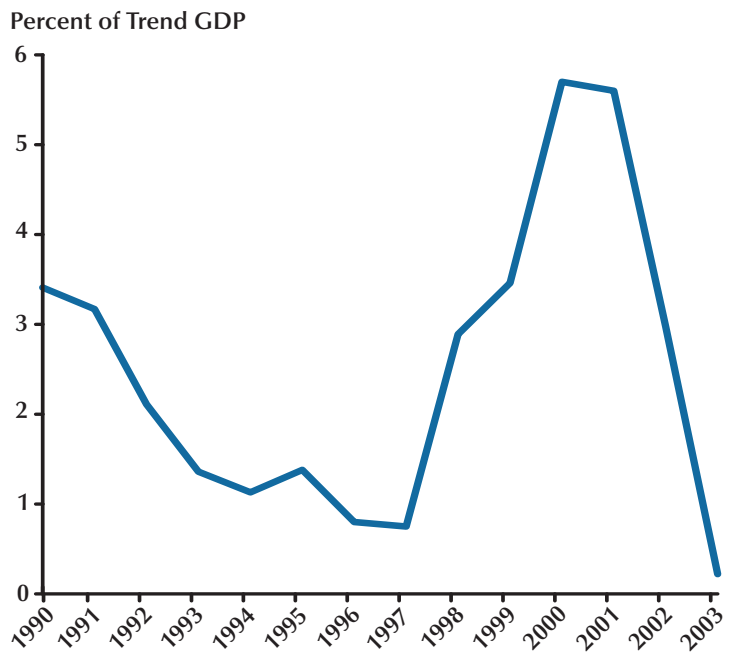

capital income shares are almost surely procyclical. The reason is simple. If accounting profits are low relative to trend, we are attributing the difference to expensed investments. However, accounting profits may appear even lower if compared with boom-time levels. When we assume that income shares vary over the cycle, then we find a larger gap between economic and accounting profits in booms and, hence, a larger amount of intangible investment.

Equation (9) and observables can be used to find the value of intangible investment in units of the consumption good as follows. Substituting for the labor shares in (9) yields

$$
\left(\frac{w_{t} \ell_{1, t}}{p_{1, t} y_{1, t}}\right)\left(\frac{p_{2, t} y_{2, t}}{w_{t} \ell_{2, t}}\right)=\frac{1-\theta}{1-\alpha} .
$$

This equation can be solved for corporate value added, $p_{1, t} y_{1, t}$, as a function of observables. Variable $p_{1, t} y_{1, t}$ can be used along with accounting value added in the corporate sector to find the value of unmeasured investment, that is,

$$
q_{t} x_{1 u, t}=p_{1, t} y_{1, t}-\mathrm{va}_{1, t}^{\text {accounting }} .
$$

In Figure 5, we plot the equilibrium path for

\section{Figure 6}

\section{Productivity Relative to a 2 Percent Trend (Corporate Income Shares Varying)}

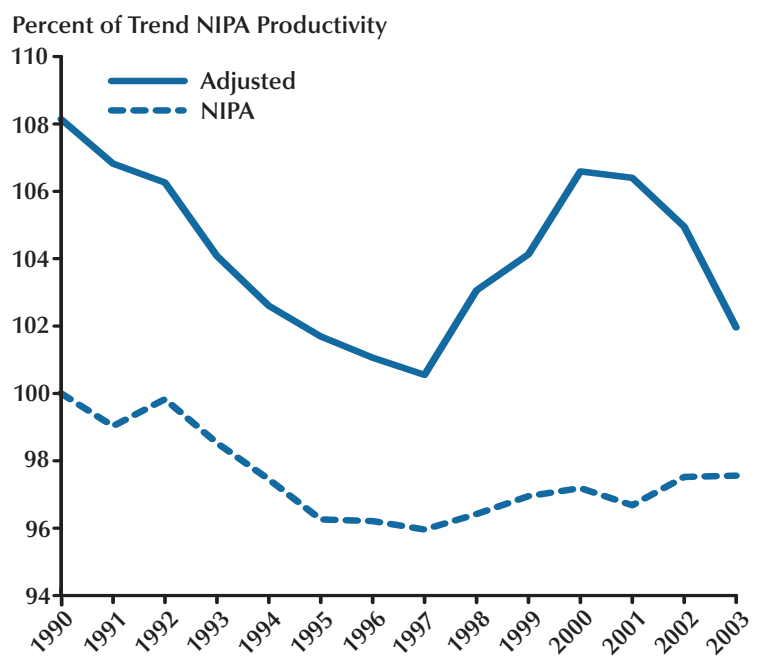

the implied investment in intangibles. As before, we find a sixfold increase in the level of intangible investments between 1997 and 2000. The main difference between the measures in Figure 1 and Figure 5 are the magnitudes. Assuming varying income shares implies a higher absolute value of intangible investment at the peak in 2000.

What are the consequences for productivity? In Figure 6, we compare the standard measure of productivity, real GDP per hour worked, with the economic measure $y_{t} / \ell_{t}$ adjusted for the intangible investment in Figure 5. Again, we normalize hours to be 1 in 1990 so that we can directly compare the magnitudes of GDP and $y$. We also divide both measures by $1.02^{t}$, the historical trend.

As in the case of fixed corporate shares, we find that economic productivity fell faster than accounting productivity in the early 1990s but grew much faster at the end of the 1990s. The rise in productivity is somewhat higher in the case where corporate income shares vary. Over the period 1997-2000, we estimate that productivity rose 3.2 percent per year in the case with fixed corporate income shares and 4 percent per year in the case with varying corporate income shares. 
However, both cases show a much different picture than GDP per hour.

\section{SUPPORTING EVIDENCE}

As we noted earlier, we do not have direct measures of all intangible investments. But there are some direct measures of one important component of intangible investment, namely, research and development. In Figure 7, we plot expenditures for research and development performed by industry. Some of these expenditures are capital expenditures and therefore are not included in our notion of intangible investments. However, we find a similar pattern of investment. Investment in research and development fell rapidly in the first half of the 1990s and rose rapidly in the second half. This is what we find for total intangible investment.

\section{SUMMARY}

U.S. growth in GDP per hour worked, which we call accounting productivity, was well below trend in the 1973-95 period and then recovered to the historical level of 2 percent per year growth beginning in 1995. (See Figure 2.) This picture is what most of the leading researchers in productivity accounting find. ${ }^{11}$ They, as do we, use hours worked estimates based on the Current Population Survey. ${ }^{12}$

We find that economic productivity, which includes corporate intangible investment in output, displays a very different pattern. As shown in Figure 2, we find that there was a productivity growth boom in the late 1990s with productivity

${ }^{11}$ See, for example, Jorgenson, Ho, and Stiroh (2003, p. 45) and Groningen Growth and Development Centre and The Conference Board (2004).

12 There are two other measures of U.S. hours worked. The BEA estimate, which uses state unemployment tax records to estimate the number of paid workers, and the BLS estimate, which uses an establishment survey to estimate the number of paid workers. The BEA hours estimate, which is an annual series, paints the same picture as CPS hours. The BLS hours estimate, which is a quarterly series, paints a different picture in the post-2000 period. With the BLS estimate of aggregate hours, estimated productivity growth is 1 percent higher in the 2000-03 period. See Kunze (2004) and Eldridge, Manser, and Otto (2004) for details.

\section{Figure 7}

\section{Industry Research and Development}

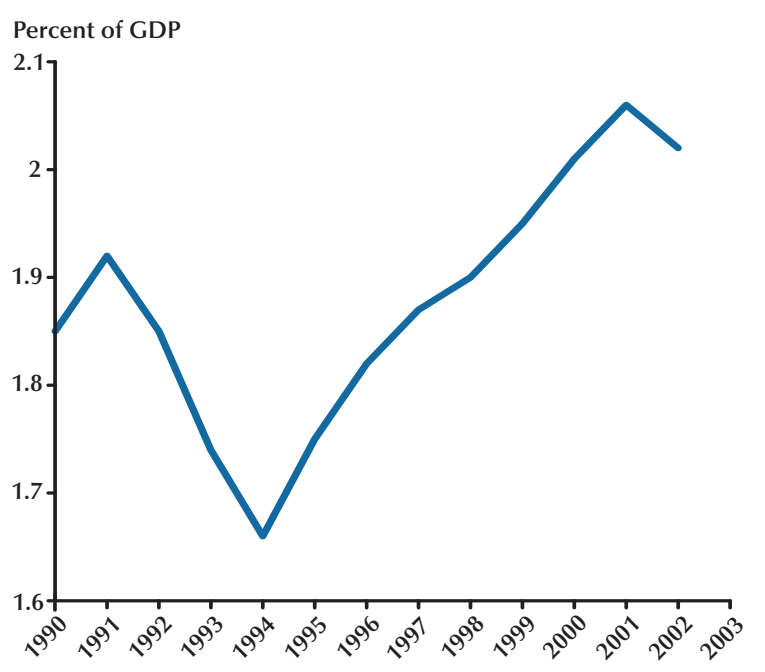

growth well in excess of the 2 percent historical trend. Prior and subsequent to this boom, average productivity growth was about half of the level of trend growth.

Our accounting resolves the puzzle of why corporate accounting profits were so low in the late 1990s boom. Corporations were making large intangible investments, which lowered their accounting profits, but not their economic profits. The economic profits share of economic income was high in the boom. (See Figure 3.) Our accounting also resolves the puzzle of why investment share of output was not much higher in this boom than standard accounting figures indicate. With the accounting numbers dictated by economic theory, the share increases, and increases a lot in the boom. (See Figure 4.)

\section{REFERENCES}

Board of Governors of the Federal Reserve System (1945-2004). Flow of Funds Accounts of the United States. Washington, DC: Federal Reserve System.

Eldridge, Lucy P.; Manser, Marilyn E. and Otto, Phyllis Flohr. "Alternative Measures of Supervisory 
Employee Hours and Productivity Growth.” Monthly Labor Review, April 2004, 127(4), pp. 9-28.

Groningen Growth and Development Centre and The Conference Board. Total Economy Database, 2004; www.ggdc.net.

Jorgenson, Dale W.; Ho, Mun S. and Stiroh, Kevin J. "Lessons for Europe from the U.S. Growth

Resurgence." CESifo Economic Studies, 2003, 49(1), pp. 27-47.

Kunze, Kurt. “U.S. Hours Worked Data.” Memo, Bureau of Economic Analysis, August 2004.
McGrattan, Ellen R. and Prescott, Edward C. "Taxes, Regulations, and the Value of U.S. and U.K. Corporations." Staff Report 309, Federal Reserve Bank of Minneapolis, 2004 (forthcoming in Review of Economic Studies).

Prescott, Edward C. and Ueberfeldt, Alexander. "U.S. Hours and Productivity Behavior Using CPS Hours Worked Data: 1959-I to 2003-II." Unpublished manuscript, Federal Reserve Bank of Minneapolis, 2003.

U.S. Department of Commerce, Bureau of Economic Analysis (1929-2004). Survey of Current Business. Washington, DC: U.S. Government Printing Office.

\section{APPENDIX}

In this appendix, we display the national accounts that we work with, the NIPA categories before we make our adjustments, and a mapping from the national accounts to the model accounts. Table A1 lists the account categories for our model along with formulas for variables in the model. Table A2 lists the NIPA categories along with average values relative to GDP in the 1990s, which give the reader a sense of the magnitudes of the adjustments. Table A3 provides a mapping between these accounts. In the main text, we provide justifications for the calculations summarized here.

\section{Table A1}

\section{Model Economy Accounts}

Model expression

\begin{tabular}{lll}
\hline 1 & Corporate domestic value added & $p_{1} y_{1}$ \\
2 & Depreciation & $\delta_{1 m} k_{1 m}$ \\
3 & Labor income & $w \ell_{1}$ \\
4 & Capital income & $r_{1 m} k_{1 m}+r_{1 u} k_{1 u}-\delta_{1 m} k_{1 m}$ \\
5 & Noncorporate domestic value added & $p_{2} y_{2}$ \\
6 & Depreciation & $\delta_{2 m} k_{2 m}$ \\
7 & Labor income & $w \ell_{2}$ \\
8 & Capital income & $r_{2 m} k_{2 m}-\delta_{2 m} k_{2 m}$ \\
9 & Total domestic value added & $y$ \\
Domestic Product & \\
10 & Private consumption & $\mathrm{c}$ \\
11 & Public consumption & $\mathrm{g}$ \\
12 & Corporate measured investment & $x_{1 m}$ \\
13 & Corporate unmeasured investment & $q x_{1 u}$ \\
14 & Noncorporate investment & $x_{2 m}$ \\
15 & Total domestic product & $y$ \\
\hline
\end{tabular}




\section{Table A2}

\section{National Accounts, Average in 1990s Relative to GDP}

1 Corporate domestic value added 0.589

2 Consumption of fixed capital 0.066

3 Compensation of employees $\quad 0.378$

4 Corporate profits with IVA and CCadj $\quad 0.075$

$5 \quad$ Taxes on production and imports ${ }^{1} \quad 0.056$

$6 \quad$ Net interest and miscellaneous payments $\quad 0.013$

7 Noncorporate domestic value added $\quad 0.400$

8 Consumption of fixed capital 0.053

9 Compensation of employees $\quad 0.240$

10 Rental income of persons with IVA $\quad 0.014$

11 Proprietors' income with IVA and CCadj $\quad 0.068$

12 Taxes on production and imports ${ }^{1} \quad 0.020$

13 Net interest and miscellaneous payments $\quad 0.051$

14 Statistical discrepancy $\quad 0.011$

15 Total domestic value added $\quad 1.000$

Domestic Product

16 Personal consumption expenditures $\quad 0.670$

17 Durable goods $\quad 0.082$

$18 \quad$ Nondurable goods and services $\quad 0.588$

19 Government consumption expenditures and gross investment $\quad 0.189$

20 Consumption expenditures 0.156

$21 \quad$ Gross investment 0.033

22 Gross private domestic investment ${ }^{2}$

23 Corporate $\quad 0.099$

$24 \quad$ Noncorporate $\quad 0.055$

25 Net exports of goods and services $\quad-0.013$

26 Total domestic product 1.000

Addendum

27 Consumption taxes 0.047

28 Consumption of fixed capital, durable goods 0.062

29 Current-cost net stock of government fixed assets $\quad 0.604$

30 Current-cost net stock of consumer durable goods $\quad 0.308$

NOTE: IVA, inventory valuation adjustment; CCadj, capital consumption adjustment.

1 This category includes business transfers and excludes subsidies.

2 The breakdown into corporate and noncorporate investments is based on data from the Flow of Funds Accounts (Board of Governors of the Federal Reserve System, 1945-2004). For corporate investment, we sum investment of nonfinancial corporate business, financial corporations, and 10 percent of farm business. 
Table A3

Mapping from National Accounts to Model Accounts' ${ }^{1}$

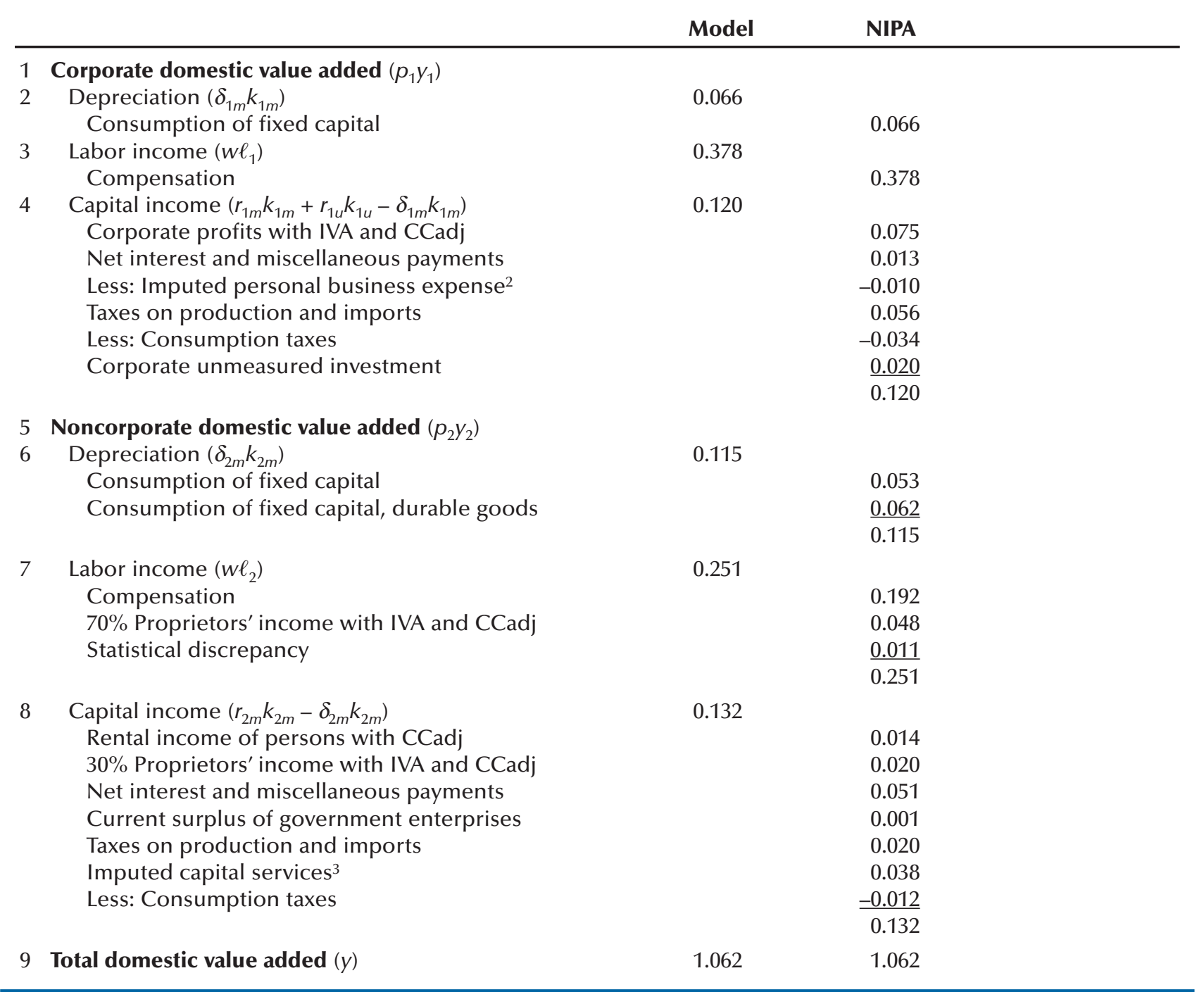




\section{Table A3 cont'd}

Model

\section{Domestic product}

10 Private consumption (c)

Personal consumption expenditures

Less: Consumption taxes

Imputed capital services ${ }^{3}$

Consumption of fixed capital, durable goods

Less: Consumption expenditures, durable goods

Less: Imputed personal business expense ${ }^{2}$

11 Public consumption (g)

Government consumption expenditures

Imputed capital services ${ }^{3}$

12 Corporate measured investment $\left(x_{1 m}\right)$

Gross domestic private investment, corporate

13 Corporate unmeasured investment $\left(q x_{1 u}\right)$ Corporate unmeasured investment

14 Noncorporate investment $\left(x_{2 m}\right)$

Gross domestic private insurance, noncorporate

Personal consumption expenditures, durable goods

Less: Consumption taxes

Government investment

Net exports

\section{Total product $(y)$}

0.611

NIPA

0.670

$-0.042$

0.013

0.062

$-0.082$

$\underline{0.010}$

0.611

0.180

0.156

$\underline{0.025}$

0.180

0.099

0.020

0.099

0.020

0.152

0.055

0.082

$-0.005$

0.033

$-\underline{0.013}$

0.152

1.062

NOTE: ${ }^{1}$ Model and NIPA values based on averages over 1990s in Table A2.

2 Expense is for handling life insurance and pension plans.

${ }^{3}$ Imputed capital services are equal to 4.1 percent times the current-cost net stock of government fixed assets and consumer durable goods. 
